\title{
Hearing Function among Squadron 11/Attack Helicopter Pilots in 2019-2020
}

\author{
Sigit Sasongko ${ }^{1 *}$, Awan Buana ${ }^{2}$, Dara Fuji Rahayu ${ }^{3}$, Wildan Kurniawan ${ }^{4}$ \\ ${ }^{1}$ ENT Dept. of Gatot Soebroto Army Central Hospital \\ Jakarta, Indonesia \\ ${ }^{2}$ Eye Laboratory, Medical Faculty of General Achmad Yani University \\ Cimahi, Indonesia \\ ${ }^{3}$ Medical Committee of Dustira Army Hospital \\ Cimahi, West Java, Indonesia \\ ${ }^{4}$ ENT Dept. Medical Faculty of General Achmad Yani University \\ Cimahi, Indonesia \\ *Corresponding author's email: sieragoiftht [AT] yahoo.com
}

\begin{abstract}
Noise-Induced Hearing Loss (NIHL) is sensorineural deafness resulting from prolonged exposure to loud noise. In the military environment, personnel with NIHL are often found. One of the professions that are at risk for NIHL is an aviator. Some of the factors that influence the degree of deafness are age and length of work. This research is a descriptive quantitative observational study with a cross-sectional design. The research subjects were Squadron 11/Attack helicopter pilots at Achmad Yani Air Base, Semarang, totaling 32 pilots, which were taken from medical record data. Sampling was done by total sampling. The data obtained were processed using SPSS and grouped into tables accompanied by descriptive explanations of each characteristic. The audiogram results showed that 32 pilots were normal, across all age and length of service categories. This result is due to the appropriate use of hearing protection device (HPD), in the form of a helmet that reduces noise up to $14 \mathrm{~dB}$ at $250 \mathrm{~Hz}, 21 \mathrm{~dB}$ at 1000 $\mathrm{Hz}, 26 \mathrm{~dB}$ at $2000 \mathrm{~Hz}, 37 \mathrm{~dB}$ at $4000 \mathrm{~Hz}$, and $42 \mathrm{~dB}$ at a frequency of $8000 \mathrm{~Hz}$, which pilots use. The pilot's working time is relatively short with a flight training schedule only 2 times a week and a flight time of around 2-3 hours. The conclusions of the study showed a description of normal hearing function in all Squadron 11/Attack helicopter pilots, based on age and length of service.
\end{abstract}

Keywords-hearing function, helicopter pilot

\section{INTRODUCTION}

Hearing impairment is one of the abnormalities in the ear organs that are often found in society, thus affecting the quality of life of a person. According to the World Health Organization (WHO) in 2012, more than 360 million (5.3\%) of the world population, almost half of them from Southeast Asia, experience hearing loss caused by noise. According to the National Committee for Deafness and Hearing Loss, in 2014, NIHL in Indonesia was among the highest in the Southeast Asia region, with nearly 36 million people or $16.8 \%$ of the population. Noise is an unwanted sound and disturbing or even bad for health. Based on Agreement of Indonesian Labor Ministry No. 13, 2011, the noise threshold value is $85 \mathrm{~dB}$, the duration of activity allowed is 8 hours/day or about 40 hours/week.[1-3]

Currently, WHO is designing a program called Sound Hearing 2030. The program aims to prevent and minimize hearing loss and improve the quality of life for people with hearing loss by developing a comprehensive, inclusive, and sustainable ear care and hearing function program both at the regional and national levels by providing facilities, technical support, guidance, information, monitoring, and evaluation. $[4,5]$

When there is prolonged exposure to noise, it will result in hearing loss, it is referred to as Noise-Induced Hearing Loss (NIHL). If noise exposure persists and lasts a long time, it will result in persistent and irreversible degeneration of the organ of Corti. The impact of hearing loss due to noise will also be permanent and irreversible, so that surgery or other medical measures cannot be taken to correct this situation. For this reason, early diagnosis before hearing loss occurs is very important. Several risk factors can affect the severity of deafness, namely individual sensitivity, noise intensity, frequency, length of daily exposure, years of service, age, and several other factors.[6,7]

In the military working domain, NIHL is common. In Indonesia, particularly in Semarang, $1.6 \%$ experienced mild hearing loss, $0.2 \%$ moderate and severe hearing loss. The military infrastructure used for national defense purposes, such as helicopters used by the Indonesian Armed Forces as air transportation or as combat equipment, pose a risk to its users, due to exposure to noise generated by engine noises or propeller sounds. Especially for helicopter pilots, according to their daily tasks, 3 of the total pilots will always be exposed to noise with a relatively higher and longer intensity. The crew of 
the Indonesian Air Force helicopters is exposed to noise between $86-117 \mathrm{~dB}$ with an NIHL prevalence of around $27.16 \%$. $[8-15]$

\section{MATERIALS AND METHODS}

The research method used was descriptive observational quantitative with cross-sectional design. The sample size was all pilots (total sampling), and research subjects were taken from medical record data (secondary data) of the Squadron 11/Attack pilots who had carried out periodic annual medical check up at the Achmad Yani Field Health Army Detachment for the 2019- 2020 period. The inclusion criteria are pilots who are registered and as members of the Squadron 11/Attack, who are still actively flying helicopters, and have at least 1 -year of experience.

The research procedure starts from initial preparation (submitting research titles), submitting Ethical Clearance approval through the Health Research Ethics Commission at Medical Faculty of General Achmad Yani University/Dustira Army Hospital, then submitting a permit request to the Head of Field Health Army Detachment to collect data. The data collected is secondary data in the form of medical records of the Squadron 11/Attack pilots. Data were collected based on the inclusion criteria and after the data was collected then analyzed and presented in tabular form along with descriptive explanations of each characteristic.

The research was conducted at Achmad Yani Field Health Army Detachment, Semarang from September 2020 until January 2021. This research was approved by the Health Research Ethics Commission at Medical Faculty of General Achmad Yani University/Dustira Army Hospital with protocol number M1.2009.027 and approval number 037/UMI.10/2020 on October 12, 2020).

\section{RESULTS AND DISCUSSION}

This study aimed to describe the hearing function and its characteristics based on age and length of service among the Squadron 11/Attack helicopter pilots for the 2019-2020 period. Existing medical record data includes age, service length, and audiogram images of 32 pilots.

\section{A. Hearing Function}

The audiogram results among Squadron 11/Attack pilots in 2019-2020 showed normal. Of a total of 32 subjects, none fit into the NIHL category. The results were presented in Table 1.

TABLE 1. HEARING FUNCTION BASED ON AUDIOGRAM

\begin{tabular}{|c|l|c|c|}
\hline \multirow{2}{*}{ No. } & \multicolumn{2}{|l|}{ Audiogram Result } \\
\cline { 2 - 4 } & Result & Number & Percentage (\%) \\
\hline 1. & Normal & 32 & 100 \\
\hline 2.NIHL & NIH & 0 & 0 \\
\hline \multicolumn{2}{|c|}{ Total } & $\mathbf{3 2}$ & $\mathbf{1 0 0}$ \\
\hline
\end{tabular}

Pure tone audiometric examinations among Squadron 11/Attack pilots are carried out once a year and include an annual routine check-up. Routine checks are carried out once a year according to the pilot's date of birth. The audiometric

examination is an examination to assess hearing function using an audiometer. Based on the audiometric examination results (Table 1), None of Squadron 11/Attack pilots experienced NIHL. It may be due to the appropriate use of HPD. The pilots using a helmet that can reduce noise up to $14 \mathrm{~dB}$ at a frequency of $250 \mathrm{~Hz}, 21 \mathrm{~dB}$ at a frequency of $1000 \mathrm{~Hz}, 26 \mathrm{~dB}$ at a frequency of $2000 \mathrm{~Hz}, 37 \mathrm{~dB}$ at a frequency of $4000 \mathrm{~Hz}$, and $42 \mathrm{~dB}$ at a frequency of $8000 \mathrm{~Hz}$.[10]

The pilot applies work risk control by using the appropriate HPD. Helicopter noise, which initially exceeds the threshold value $(85 \mathrm{~dB})$, can be reduced with an HPD in the form of a helmet. The helmet can protect against noise up to more than $110 \mathrm{~dB}$. In Squadron 11/Attack pilots, the helmets used are HGU-56/P (for Bell-412 helicopter pilots) and Apache Block III helmets (for Boeing AH-64 Apache helicopter pilots). Both helmets can reduce up to $14 \mathrm{~dB}$ at a frequency of $250 \mathrm{~Hz}, 21$ $\mathrm{dB}$ at a frequency of $1000 \mathrm{~Hz}, 26 \mathrm{~dB}$ at a frequency of $2000 \mathrm{~Hz}, 37 \mathrm{~dB}$ at a frequency of $4000 \mathrm{~Hz}$, and $42 \mathrm{~dB}$ at a frequency of $8000 \mathrm{~Hz}$. Squadron 11/Attack has implemented technical and administrative controls by conducting periodic audiogram evaluations. It is an implementation of the Hearing Conservation Program (HCP) based on NIOSH 1996, which aims to prevent the adverse effects of noise.[8, 11, 16-19]

Besides the use of helmets, Squadron 11/Attack has implemented good HCP for the safety and health of pilots. The program aims to protect and prevent work accidents, namely the occurrence of NIHL. Exposure to noise that occurs with high intensity causes perceptual disturbances in daily communication. It has the potential to increase the risk of quality of life disruption if HCP not implemented.[5, 9, 10, 13, 16] 
Apart from the appropriate application of the HCP, the pilot's work intensity is also one of the risk factors of NIHL. The flight intensity in Squadron 11/Attack pilots is relatively short, with the flight training schedule is only two times a week with a flight time of around 2-3 hours.

\section{B. Hearing Function Based on Age and Years of Service}

Squadron 11/Attack pilots were dominated by the 30-40 years age group, amounting to 17 pilots (53.1\%), followed by ten pilots aged less than $30(31.3 \%)$, and the rest of them aged more than 40 years, amounting to 5 pilots (15.6\%). In the 20 29 age group, all of them have less than 10-years of work experience. In the age group of 30-40 years, 12 persons had less than 10-years of work experience, and 5 had work experience of more than or equal to 10 years. For the $>40$ years age group, only a person has less than 10-years of work experience, and four persons have work experience of more than or equal to 10 years. The audiogram results based on age and length of work (service length) showed normal hearing function (Table 2).

TABLE 2. HEARING FUNCTION BASED ON AGE AND LENGTH OF WORK
\begin{tabular}{|c|c|r|r|r|r|}
\hline $\begin{array}{c}\text { Lene } \\
\text { (Years } \\
\text { old) }\end{array}$ & $<\mathbf{1 0}$ & centage $(\boldsymbol{\%})$ & $\mathbf{2 1 0}$ & centage $\mathbf{\%})$ & \\
\hline $20-29$ & 10 & 100 & 0 & 0 & Result \\
\hline $30-40$ & 12 & 70,6 & 5 & 29,4 & Normal \\
\hline$>40$ & 2 & 20 & 4 & 80 & Normal \\
\hline
\end{tabular}

The characteristics assessed in Table 2 are the age and length of work of the Squadron 11/Attack pilots. The age of the pilot is the age at the time of carrying out the last routine inspection. This study found that the youngest pilot was 23 years old, and the oldest was 45 years old. The mean age of all pilots was 32.72 years.

The service length is calculated since being registered as a pilot in Squadron 11/Attack until 2020. In research subjects, the longest service is twenty years, and the shortest is three years. The overall average length of employment was 7.34 years.

The length of work has a significant effect on the incidence of hearing loss. Workers with more than ten years of work have a five times greater risk of hearing loss. One method to control NIHL is to reduce the intensity of the noise source.[2, $12,20]$

According to research conducted in Lampung in 2017, the older a person is, the incidence of hearing loss will increase. It can occur because in the older there is a relative decrease in sensitivity to sound stimuli due to the aging process, the degenerative process of the hearing organs, which generally starts from the age of 40 years and over.[21] The results of that study differed from the results of audiometric examinations on Squadron 11/Serbu pilots, which showed no abnormalities. It indicates that the age group over 40 years also has a normal hearing function because the pilots have implemented the HCP correctly.

Another study conducted in South Jakarta (in 2012) showed that hearing loss was more common in workers with a length of service of more than ten years.[12] This study also showed different results because the audiogram results of all Squadron $11 /$ Serbu pilots showed no abnormalities, even though these pilots had a length of service of more than ten years. It is due to the short duration of flight training ( 2 times a week with a flight time of only 2-3 hours), and they also use HPD properly.

This conclusion, that the auditory function description of the audiogram results of all swuadron-11 / Attack helicopter pilots for the periode 2019-2020 based on age and length of work duration overall shows normal results.

\section{ACKNOWLEDGMENT}

Our gratitude goes to the professionals who have helped the research process and the preparation of manuscripts including the Field Health Army Detachment, Achmad Yani in Semarang.

\section{REFERENCES}

[1] Taneja MK. Noise Induced Hearing Loss. Indian J Otol. 2014;20(4):151- 4

[2] Septiana NR, Widowati E. Gangguan Pendengaran Akibat Bising. HIGEIA J Public Heal Res Dev. 2017;1(1):73-82. http://journal.unnes.ac.id/sju/index.php/higeia.

[3] Menteri Kesehatan Republik Indonesia. Peraturan Pemerintah tentang Kebisingan yang Berhubungan dengan Kesehatan. Indonesia; 1987.

[4] Sound Hearing 2030. Society for Sound Hearing. http://www.soundhearing2030.org/about.php. Published 2010. Accessed April 9, 2020.

[5] Garcia SL, Smith KJ, Palmer C. Cost-Effectiveness Analysis of a Military Hearing Conservation Program. Mil Med. 
2018;183(9-10):547-53.

[6] Soepardi EA, Iskandar N, Bashiruddin J. Gangguan Pendengaran. In: Soepardi EA, ed. Buku Ajar Ilmu Kesehatan Telinga Hidung Tenggorok Kepala dan Leher. 7 ed. Jakarta: Badan Penerbit FK UI; 2012:17-20.

[7] Suwento R. Standar Pelayanan Indera Pendengaran di Puskesmas. Kom Nas Gangguan Pendengaran dan Ketulian. 2007.

[8] Collee A, Legrand C, Govaerts B, Der Veken Paul V, De Boodt F, Degrave E. Occupational Exposure to Noise and The Prevalence of Hearing loss in a Belgian military population: A cross-sectional study. Noise Heal. 2011;13(50):6470.

[9] Muhr P, Rosenhall U. The Influence Of Military Service On Auditory Health and The Efficaci Of a Hearing Conservation Program. 13 ed.; 2011.

[10] Mahardana KN, Suardana W, Puteri S, Sudana W. Efek Letusan Senjata Api Ringan Terhadap Fungsi Pendengaran Pada Siswa Diktuba POLRI. 2008;1(August):1-12.

[11] Maulana I, Jayanti S, Suroto S. Analisis Implementasi Hearing Conservation Program Di Pt Kaltim Prima Coal. $J$ Kesehat Masy. 2016;4(4):682-9.

[12] Dewi Pratiwi. Pengaruh Tingkat Kebisingan Pesawat Herkules Dan Helikopter Terhadap Terjadinya Gangguan Pendengaran Pada Penerbang Tni Au. J Fak Kedokt Univ Sebel Maret Surakarta. 2012.

[13] Mulyono M, Kandou L. Hubungan Karakteristik dengan Peningkatan Ambang Pendengaran Penerbang di Balai Kesehatan Penerbangan Jakarta. Indones J Occup Saf Heal. 2013;2(1):1-9.

[14] Nurfitriyana, July I, Pramusinto A. Faktor-faktor yang Berhubungan dengan Terjadinya Gangguan Pendengaran pada Pilot Helikopter dan Casa. 2020;2(5):22-30.

[15] Kemenakertrans RI. Permenakertrans No. Per.13/MEN/X 2011 tentang Nilai Ambang Batas Faktor Fisika dan Faktor Kimia di Tempat Kerja. Permenakertrans No Per13/MEN/X/2011 tentang Nilai Ambang Batas Fakt Fis dan Fakt Kim di Tempat Kerja. 2011:1-54.

[16] Buchari. Kebisingan Industri dan Hearing Conservation Program. USU Repos. 2007. http://repository.usu.ac.id/handle/123456789/1435.

[17] PT Safety Sign Indonesia. Standar Internasional EN 352: Panduan Memilih Alat Pelindung Pendengaran yang Tepat. www.SafetySign.co.id.

[18] Corporation G. High Performance Flight Equipment. Gentex Corporation; 2017. gentexcorp.com.

[19] Gerges SN, Sehrndt GA. Personal Measures and Hearing Conservation. Dortmund;2014.https://www.who.int/occupational_health/publications/n oise11.pdf.

[20] Syah PB. Faktor yang Mempengaruhi Noise Induced Hearing Loss dan Tinitus pada Pekerja Bengkel Mesin Terpapar Bising di PT DOK dan Perkapalan Surabaya. Univ Airlangga. 2016;30(28). http://repository.unair.ac.id/35236/.

[21] Eryani YM, Wibowo CA, Saftarina F. Faktor Risiko Terjadinya Gangguan Pendengaran Akibat Bising. Bagian Ilmu Kedokt Komun Fak kedokteran, Univ Lampung. 2017;7:112-7. 